\author{
Professor Liviu Stelian BEGU, PhD \\ Department of Statistics and Econometrics \\ The Bucharest University of Economic Studies \\ E-mail: liviu.begu@ csie.ase.ro \\ Associate Professor Ioana Teodora MESTER, PhD \\ Lectures Ramona SIMUT, PhD \\ Lectures Mariana SEHLEANU, PhD \\ Lectures Diana PERTICAS, PhD \\ Department of Economics and Business \\ University of Oradea, Oradea
}

\title{
ECONOMIC AND ENVIRONMENTAL IMPLICATIONS OF ENERGY TAXES: EVIDENCE FROM ROMANIA
}

\begin{abstract}
This study investigates the relationship between the energy taxes from Romanian and several explanatory variables related to economic growth, carbon dioxide emissions, renewable and non-renewable energy in the country. After reviewing the main relevant aspects and contributions related to the relation between these variables, we launched and tested three hypotheses related to the possible causal relationship between energy taxes, gross domestic product (GDP), carbon dioxide emissions $\left(\mathrm{CO}_{2}\right)$, renewable energy types and non-renewable energy by using the Johansen cointegration test and Granger causality. The Granger causality test yields evidence of a long-run Granger causality running from: GDP to energy taxes, $\mathrm{CO}_{2}$ to energy taxes, renewable energy types to energy taxes, respectively from energy taxes to $\mathrm{CO}_{2}$, renewable and non-renewable energy types. Regarding the evidence of a short-run unidirectional causal relationship between variables, there is one from $\mathrm{CO}_{2}$ and non-renewable to energy taxes, respectively from energy taxes to renewable energy types. emission.

Keywords: energy; tax; economic growth; renewable energy; carbon dioxide

\section{JEL classification: C32, O4, Q2, Q4, Q3}

\section{Introduction}

In the context of ensuring sustainable development, the study of the influence of environmental taxes, both from an economic and environmental perspective, becomes crucial. Knowing the implications, policy makers can design and adapt the
\end{abstract}

DOI: $10.24818 / 18423264 / 53.3 .19 .02$ 
energy policy in a proper way. It is important that policy makers and governments promote the use of renewable energy sources and the increase of the share of nonfossil fuel. Moreover, the issue of climate change imposes finding solutions in order to mitigate the impact of $\mathrm{CO}_{2}$ emissions by using renewable resources. The implementation of strategies to reduce greenhouse gas emissions represents a major concern globally and it must target both the industrial level and the household level. All these issues explain the major interest shown by researchers in the field literature towards the topic of the effects of environmental taxes.

The aim of our research is to identify and highlight the economic and ecological implications of energy taxes in Romania. In this sense, we intend to study the causal relationship between energy taxes and Romania's GDP, whether it is a unidirectional or bidirectional influence between the variables. Also, we want to study in which way energy taxes influence the consumed energy (renewable and nonrenewable energy) in Romania and if there is a relationship, unidirectional or bidirectional, between energy taxes and $\mathrm{CO}_{2}$ emissions. We consider that our research has important implications from an economic as well as from an environmental point of view.

\section{Literature review}

At the European Union level, the environmental tax reform was carried out with the purpose of achieving the EU's sustainable development goal. Otherwise, Ekins et al. (2012) discussed about environmental tax reform that was implemented on a small scale in some European countries and constructed scenarios with low and high international energy prices which showed that the environmental tax reform results in increased carbon productivity (GDP per unit of carbon) and materials productivity (GDP per unit of consumption) but reduced labour productivity, with the emission reductions distributed across all sectors as a reduction in the demand for all fossil fuels. Also, the simulation results showed that in most countries (and for the EU as a whole), but not all, there are small increases in GDP, as a result of environmental tax reform, equivalent to a quarter's growth over the period up to 2020. The research of Verbič et al. (2017) revealed that energy intensity in Europe was favorably affected by the restructuring of industrial companies in transitional economies, the implementation of national programmes for improving the energy efficiency, and the introduction of EU Emissions Trading Scheme. Cioca et al. (2015) analyzed Romania's involvement in actions aimed to reduce pollutants and greenhouse gases and they concluded that our country is making substantial efforts to reduce $\mathrm{CO}_{2}$ emissions. Thus, Romania adopted strategies aligned to European guidelines regarding the use of renewable energy and also effective waste management policies. Badulescu et al. (2016) empirically found that an increase of Romania's GDP predicts an increase of 
environmental protection expenditure by public or private specialized providers and that there is a tendency that this effect will accelerate in time. The actions towards environmental protection require significant expenditure, but unfortunately, their efficiency is not ensured.

In a research that covered the period 1995-2004, Ryan et al. (2009) investigated the impact of national fiscal measures in the EU15 on passenger car sales and the intensity of $\mathrm{CO}_{2}$ emissions of the new car fleet. Their results indicated that national vehicle and fuel taxes influenced passenger car sales and fleet $\mathrm{CO}_{2}$ emissions. Lin and $\mathrm{Li}$ (2011) investigated the effect of an environmental tax i.e. the carbon tax on $\mathrm{CO}_{2}$ emissions per capita in several countries and they showed that, in Finland, this tax imposes a significant and negative impact on the increasing of $\mathrm{CO}_{2}$ emissions per capita; in countries like Denmark, Sweden and Netherlands the influence of this tax is negative but not significant, while in Norway carbon tax has not achieved a mitigation effect on $\mathrm{CO}_{2}$ emissions.

Chen et al. (2016) studied the relationship between economic growth, energy consumption and $\mathrm{CO}_{2}$ emissions for 188 countries, in the period 1993-2010. Researchers found a long-run relationship between economic growth, energy consumption and $\mathrm{CO}_{2}$ emissions for all the countries included in the study. Energy consumption has a negative influence on GDP in the world, in developing countries, except for the developed ones. The study revealed a unidirectional causality from energy consumption to $\mathrm{CO}_{2}$ emissions in the developing countries as well as in the developed ones.

In a recent study, Fotis et al. (2017) investigated the relationship between energy demand and real GDP growth in 34 countries, over the period 2005-2013, and they drew several conclusions. Thus, they found that energy demand is elastic in the industrial sector as well as in the household/services sectors and electricity and natural gas represent demand substitutes. Regarding the relationship between real per capita GDP growth rate and energy consumption per capita, they indicate that it presents an inverted U-shape.

Using Granger causality, Amri (2017) focused in his research on the relationship amongst energy consumption (renewable and non-renewable), and GDP in Algeria, over the period 1980-2012. He revealed the existence of long-run link between real GDP, real capital and energy consumption (renewable energy per capita and non-renewable energy).

Rahman et al. (2017) examined the long-run relationship between economic growth and disaggregated energy consumption in Malaysia, over the period 19712014. Their empirical findings indicate that the country's economy is energy dependent and sensitive to energy supply shocks, the use of energy inputs in the economy is consumed inefficiently so using higher energy resources does not 
contribute significantly to the economic growth, instead causes environmental pollution. Moreover, they found that economic growth and environmental pollution through spreading $\mathrm{CO}_{2}$ emissions are reactive to each other.

Based on a large panel data of 210 countries and referring to the period 19602014, Sarwar et al. (2017) found a bidirectional relationship between electricity consumption and GDP, oil price and GDP, fixed capital formation, population and GDP. They also showed that in the case of countries that use non-renewable sources to generate electricity, the electricity consumption is negatively correlated with the economic growth.

Another series of studies focus on analyzing the impact of different environmental taxes on GDP. Based on a combination of a regional Computable General Equilibrium (CGE) model with a microsimulation framework, Vandyck and Regemorter (2014) investigated the distributional and regional economic impact of energy taxes in Belgium and found that energy tax increase raises production costs, influences the country's GDP (in volume) negatively and it affects more the regions with energy-intensive industries.

Filipović et al. (2015) empirically analysed the determinants of energy intensity in EU-28 member states, over the period 1990-2012. Their estimated model revealed that energy prices, energy taxes and GDP per capita have a negative influence on energy intensity. Regarding the growth of gross inland consumption and final energy consumption per capita, according to the researchers, they positively affect energy intensity.

Moutinho et al. (2017) estimated the efficiency of 26 different European Countries over the period 2001-2012, by comparing their performance, and concluded that the share of renewable and non-renewable energy sources explain differences in emissions. By observing a significant change in the trend of economic and environmental efficiency in the European countries considered in the analysis, they showed high disparities existing among the countries. The researchers indicated that environmental tax revenue effects are negatively stronger in the countries that are less efficient and that they exert negative influence also over those more eco-efficient. According to them, energy taxes have a positive influence only in the lower ecoefficient countries.

The link between environmental taxes and energy consumption has also been studied in the literature. In their study, Bjørner and Jensen (2002) focused on the relation between energy price and energy consumption, over the period 1993-1997, and concluded that energy tax determined a $10 \%$ decrease of the total energy consumption due to the carbon tax revolution. By analyzing price elasticity, they found that energy price elasticities are lower in the case of energy intensive firms compared to energy extensive firms. Another important observation is that voluntary agreements 
have led to a significant reduction in energy demand. Sundqvist (2007) found an energy saving effect for the oil tax and the petrol tax and an increased energy consumption due to the electricity tax.

\section{Energy reform in Romania during the communist and transition period}

At the end of the ' 80 s some of the European states suffered from a high degree of pollution, whether we are referring to air, water or soil pollution, of which we mention: the former German Democratic Republic (the so-called "East Germany"), the Czech Republic, Poland, the former Czechoslovakia, Bulgaria, Romania, etc. (Turnock, 2005). This was mainly due to massive deforestation and the intensive use of fossil fuels, especially low-carbon coal, whose thermal added value is low yet generating a large amount of ash and sulphur. In the case of Romania and Bulgaria, the main sources of pollution were the thermal power plants and the industrial units that were most often built near large cities, leading to the increase of the pollution of the urban and neighbouring areas.

During the '70s and '80s some concerns were raised about the degradation of the Romania's environment, but there were not made public due to the fear of the socialist regime that governed at that time. With the abolition of this regime in December 1989, access to information was no longer banned, and people's ability to research, publish and assert was no longer restricted, which in a relatively short time caused the emergence not only of non-governmental organizations but of some green oriented political parties too.

With the collapse of the socialist regime, many Eastern European countries toyed with the idea of joining the European Union, which is why environmental policies have also been reviewed. Among the countries that started accession negotiations were at that time - besides Romania - the Czech Republic, Estonia, Hungary, Poland, Slovenia, Bulgaria, Latvia, Lithuania and Slovakia.

To all the above, and when referring to the energy sector one can add that most existing equipment and installations have been outdated. Considering that large investments in this field were carried out back in the ' $70 \mathrm{~s}$ and ' $80 \mathrm{~s}$, and the maximum guaranteed operating duration of thermal and power plants is 30 years one could shape an image of the current state of play. If we also consider the technical progress abroad, we have all the reasons to believe that Romania in the coming years is very likely to become a relatively large-scale energy importer, and the implementation of the EU acquis in the field has become a challenge that is difficult to cope with.

Immediately after the Romanian Revolution of 1989, the Decree-Law no. 2/1989 (on the establishment, organization and functioning of the Council of the National Salvation Front) is the first normative act that establishes a direct link between the "safeguarding and defense of fundamental rights" and the ecological

DOI: 10.24818/18423264/53.3.19.02 
Liviu Begu, Ioana Teodora Mester, Ramona Simut, Mariana Sehleanu, Diana Perticas

balance (Teodoroiu, 2003:13). Subsequently, in 1991, the environmental protection was consecrated in the Constitution of Romania among other social obligations of the Romanian state.

Between 1997 and 1999 the first National Strategy for Sustainable Development was developed in Romania. Even if the strategy implementation outcomes and outputs were not significant, it nevertheless constituted the conceptual framework for the Agenda 21 which was to be carried out in 40 cities and counties of Romania. Romania's first concrete commitments were those included in Romania's Accession Treaty to EU signed on $25^{\text {th }}$ of April 2005, and by which our country undertook to (Government of Romania and United Nations Development Programme, 2008): replace the high-pollution industrial installations by 2015, solve the problem of land filling of domestic waste of municipalities by July $16^{\text {th }}, 2017$, expand urban water supply systems and wastewater treatment by 2018.

As far as energy taxes are concerned, they have emerged from the Council Directive 2003/96/EC of 27 October 2003 restructuring the Community framework for the taxation of energy products and electricity and according to which all energy products and electricity have to be taxed starting from 2004.

Currently, energy taxes consist of taxes levied on energy products used in transport, industry or energy sectors. The most used energy products are diesel and gasoline, and if we refer to industry, the most used energy products are those used in the production of electric and thermal energy, namely coal, natural gas, fuel, oil, etc.

If we analyze the evolution of energy taxes in Romania over the period 19952014, we can observe that this trend is increasing during almost the entire period under scrutiny. However, if we compare the value of these taxes with those applied in the most developed Members States of the European Union, we can say that Romania gets low revenues as a result of the collection of energy taxes (Eurostat).

\section{Data analysis}

In order to investigate the short and long-run relationship between the variables energy taxes (ENT), $\mathrm{CO}_{2}$ emissions $\left(\mathrm{CO}_{2}\right)$, Gross Domestic Product (GDP), renewable energy (RENEW) and non-renewable energy (NRENEW) from Romania, we used the annual time series data from Eurostat and World Bank. The data timeframe is $1995-2014$. Table 1 below includes the summary statistics for the dataset used. 
Economic and Environmental Implications of Energy Taxes: Evidence from Romania

Table 1. Descriptive statistics of variables

\begin{tabular}{cccccc}
\hline & \multicolumn{5}{c}{ Variables } \\
\cline { 2 - 6 } & $\begin{array}{c}\text { Energy } \\
\text { taxes }\end{array}$ & $\begin{array}{c}\mathrm{CO}_{2} \\
\text { emissions }\end{array}$ & $\begin{array}{c}\text { Gross } \\
\text { Domestic } \\
\text { Product }\end{array}$ & $\begin{array}{c}\text { Renewable } \\
\text { energy }\end{array}$ & $\begin{array}{c}\text { Non- } \\
\text { renewable } \\
\text { (waste) }\end{array}$ \\
\hline & $\begin{array}{c}\text { \% of } \\
\text { GDP }\end{array}$ & $\begin{array}{c}\text { metric } \\
\text { tons } \\
\text { per capita }\end{array}$ & $\begin{array}{c}\text { current } \\
\text { prices, euro } \\
\text { per capita }\end{array}$ & $\begin{array}{c}\text { Terajoule } \\
\text { Gross inland } \\
\text { consumption }\end{array}$ & $\begin{array}{c}\text { Terajoule } \\
\text { Gross inland } \\
\text { consumption }\end{array}$ \\
\hline Statistics & ENT & CO2 & GDP & RENEW & NRENEW \\
Mean & 1.94 & 4.49 & 4010 & 195114.3 & 3373.25 \\
Median & 1.75 & 4.55 & 3350 & 199482.5 & 3029.50 \\
Maximum & 3.42 & 5.70 & 7500 & 256408 & 15268 \\
Minimum & 1.38 & 3.42 & 1300 & 117077 & 0.0 \\
Std. dev. & 0.52 & 0.61 & 2365.52 & 34901.55 & 3517.1 \\
Skewness & 1.45 & 0.23 & 0.197 & -0.35 & 2.19 \\
Kurtosis & 4.61 & 2.60 & 1.332 & 2.71 & 7.87 \\
Observations & 20 & 20 & 20 & 20 & 20 \\
\hline
\end{tabular}

Source: Eurostat database for the GDP per capita, Energy tax, renewable energy and non-renewable (waste) energy case. The data regarding $\mathrm{CO}_{2}$ emissions were collected from the World Bank.

As can be seen in Table 1, the energy taxes variable is measured in \% of GDP, the $\mathrm{CO}_{2}$ emissions is measured in metric tons per capita, the GDP is measured in current prices euro per capita, while the variables renewable energy and non-renewable energy are measured in Terajoule Gross inland consumption. Only one variable is negatively skewed, while the other variables are positively skewed. Two of the variables, namely energy taxes and non-renewable energy types, have a moderately high kurtosis, while the other three variables have a small kurtosis. To ease interpretation of the coefficients, the variables are transformed through the use of natural logarithm. Coefficients in the log function are interpreted as elasticities that represent a percentage variation in a dependent variable, given a $1 \%$ change of an independent variable

The causal relationship between energy taxes and the other four selected variables $\left(\mathrm{CO}_{2}\right.$, GDP, RENEW, and NRENEW) is examined by answering three interrelated questions:

H1: Is there a short or a long-run relationship between GDP and energy tax in Romania?

$\mathrm{H} 2$ : How energy taxes affect the $\mathrm{CO}_{2}$ emissions in Romania? Is there a unidirectional or a bidirectional relationship between these two variables?

DOI: $10.24818 / 18423264 / 53.3 .19 .02$ 
Liviu Begu, Ioana Teodora Mester, Ramona Simut, Mariana Sehleanu, Diana Perticas

H3: How energy taxes affect the energy intensity in Romania (renewable energy and non-renewable)?

\section{Methodology, empirical results and discussions}

In order to test the relationship and the causality between the variables energy taxes, $\mathrm{CO}_{2}$ emissions, GDP, renewable energy and non-renewable energy (waste), the first step is to investigate the stationarity using the unit root test (Augmented Dickey Fuller test) but not before determining the number of lags underlying these tests. The number of lags shall be selected based on the AIC, SC and HQ information criterion (Akaike information criterion, Schwarz information criterion and Hannan-Quinn information criterion). Given that there is at least one unit root, the model is not stationary and passes cointegration tests. Otherwise, the VAR model is used to explain the link between variables. If the variables are cointegrated, the most appropriate model is the VECM (Vector Error Correction Model), which explains the causality test.

Therefore, the first step in identifying a long-run relationship between two or more variables is to test the stationarity of these time series by applying the Augmented Dickey Fuller (ADF).

The results of testing the order of natural logarithm of ENT, $\mathrm{CO}_{2}, \mathrm{GDP}$, RENEW and NRENEW are provided in Table 2.

Table 2. ADF unit root test

\begin{tabular}{lccc}
\hline \multicolumn{1}{c}{ Log values } & ADF (level) & ADF $\left(1^{\text {st }}\right.$ diff $)$ & $\begin{array}{c}\text { The order of } \\
\text { integration } \\
\text { for 5\% level of } \\
\text { significance }\end{array}$ \\
\hline Energy taxes & -2.914778 & -3.337014 & $\mathrm{I}(1)$ \\
CO 2 emissions & $(0.06)$ & $(0.02)$ & $\mathrm{I}(1)$ \\
GDP per capita & -2.386457 & -3.823182 & $\mathrm{I}(1)$ \\
Renewable energy & -0.677999 & -3.813990 & $\mathrm{I}(1)$ \\
Non-renewable & -2.634724 & -3.820666 & \\
& $(0.10)$ & $(0.01)$ & $\mathrm{I}(1)$ \\
\hline
\end{tabular}

Notes: p-value are in () and the optimum lag length selected based on Akaike, Schwarz and Hannan-Quinn info Criterion is 1 for all the variables. Source: authors' estimates using Eviews 9. 
Economic and Environmental Implications of Energy Taxes: Evidence from Romania

The ADF test supported the null hypothesis of non-stationarity before differencing the variables at the 5\% significance level. Therefore, we proceeded to the first differences of the non-stationary series variable and the results indicate that these series integrated to order I are stationary and do not have a unit root or the variables are stationary at first order I(1) for 10\% level of significance, respectively 5\% level of significance.

If the series of data are not stationary at level, they can be cointegrated, i.e. there is at least one linear combination between them that is stationary. In our case, the condition to be cointegrated is respected because the variables have the same order of integration. Cointegration is the property of two or more time series to have the same long-term stochastic trend. The lack of stationarity of the variables is characterized by the presence of at least one unit root in the initial representation of the autoregressive vector. This concept of cointegration was introduced first by Granger and developed by Engle and Granger. They defined the long-run relations between elements of a vector of time series as the existence of a linear combination of vector elements that is shown to be stationary (Engle and Granger, 1987). Johansen and Juselius (1990) derived a procedure, maximum likelihood, that overcame the limitation of univariate cointegration. The methodology we use to estimate the model parameters is that proposed by Johansen and Juselius (1990), according to which the null hypothesis of non-cointegration will be tested. To determine the number of cointegration relationships we can use the following two types of LR (likelihood ratio) tests, namely (Johansen and Juselius, 1990; Andrei and Bourbonnais, 2017):

the Trace test $\left(\mathrm{LR}_{\max }\right)$

$$
\mathrm{LR}_{\text {trace }}(\mathrm{r})=\lambda_{\text {trace }}(\mathrm{r})=-\mathrm{T} \sum_{\mathrm{i}=\mathrm{r}+1}^{\mathrm{k}} \ln \left(1-\hat{\lambda}_{\mathrm{i}}\right)
$$

The null hypothesis is: the non-existence of a cointegration relationship between variables. This is accepted when the statistic value is less than the critical one (for $1 \%$ or $5 \%$ significance level).

the Maximum Eigenvalue test

$$
\mathrm{LR}_{\text {max }}=\lambda_{\text {max }}(\mathrm{r}, \mathrm{r}+1)=-\mathrm{T} \ln \left(1-\hat{\lambda}_{\mathrm{r}+1}\right)
$$

In this case, the null hypothesis and the alternative one are:

$\mathrm{H}_{0}: r$ cointegration relationship,

$\mathrm{H}_{1}: r+1$ cointegration relationship, for $\mathrm{r}=0,1, \ldots, \mathrm{k}-1$.

The critical values are determined by several authors, among which we mention Johansen and Juselius (1990), Andrei and Bourbonnais (2017). The critical values differ as the series have a deterministic constant and / or trend, respectively the cointegration equations contain a constant and / or a deterministic tendency.

DOI: $10.24818 / 18423264 / 53.3 .19 .02$ 
Liviu Begu, Ioana Teodora Mester, Ramona Simut, Mariana Sehleanu, Diana Perticas

\begin{tabular}{|c|c|c|c|c|c|}
\hline \multirow{2}{*}{ Variables } & \multirow{2}{*}{$\begin{array}{c}\text { Hypothesized } \\
\text { No. of CE(s) }\end{array}$} & \multirow{2}{*}{$\begin{array}{c}\text { Trace } \\
\text { statistic }\end{array}$} & \multirow{2}{*}{$\begin{array}{l}\text { Max- } \\
\text { Eigen } \\
\text { statistic }\end{array}$} & \multicolumn{2}{|c|}{$\begin{array}{c}\text { Critical Value } \\
(5 \%)\end{array}$} \\
\hline & & & & Trace & $\begin{array}{l}\text { Max- } \\
\text { Eigen }\end{array}$ \\
\hline \multirow{2}{*}{ GDP / Energy taxes } & $\mathrm{r}=0$ & $23.02 * *$ & $22.07 * *$ & 15.49 & 14.26 \\
\hline & $\mathrm{r} \leq 1$ & 0.95 & 0.95 & 3.84 & 3.84 \\
\hline \multirow{2}{*}{ CO2 / Energy taxes } & $\mathrm{r}=0$ & $15.96^{* *}$ & $14.42 * *$ & 15.49 & 14.26 \\
\hline & $\mathrm{r} \leq 1$ & 0.54 & 0.54 & 3.84 & 3.84 \\
\hline \multirow{2}{*}{$\begin{array}{l}\text { Renewable energy / } \\
\text { Energy taxes }\end{array}$} & $\mathrm{r}=0$ & $19.17 * *$ & $18.52 * *$ & 15.49 & 14.26 \\
\hline & $\mathrm{r} \leq 1$ & 0.65 & 0.65 & 3.84 & 3.84 \\
\hline \multirow{2}{*}{$\begin{array}{l}\text { Non-renewable } \\
\text { energy / Energy } \\
\text { taxes }\end{array}$} & $\mathrm{r}=0$ & $16.10 * *$ & $13.50 * *$ & 15.49 & 14.26 \\
\hline & $\mathrm{r} \leq 1$ & 2.60 & 2.60 & 3.84 & 3.84 \\
\hline
\end{tabular}

Note: $* *$ denotes significant at $5 \%$ significance level. Lags $=1 . \mathrm{r}$ denote the number of cointegrated vectors. Source: authors' estimates using Eviews 9

With the Eviews software, we determined the number of cointegration relationships among the variables (Table 3). The results highlight the fact that there is at least one cointegration relationship between the variables because the $\lambda_{\text {statistic }}$ value $<$ the $\lambda_{\text {critic }}$ value, both for the first test and for the second test. Engle and Granger (1987) say that if there is cointegration between two time series, there is a long-run effect that prevents the two time series from drifting away from each other, that is, there exists a force of equilibrium that holds the two time series moving together in the long-run (Engle and Granger, 1987).

For each hypothesis (question) issued (H1, H2 and $\mathrm{H} 3$ ), we developed two models. In the case of the first model, we considered the Energy taxes variable as dependent, while for the second model we considered the Energy taxes variable as independent. Thus, we will continue to apply the Johansen co-integration test to identify a possible long-term relationship between Energy taxes and GDP, $\mathrm{CO}_{2}$, Renewable energy, respectively non-renewable energy. Depending on the results obtained from the Johansen-Juselius cointegration tests, we can decide the appropriateness of applying the VECM model for each model/hypothesis in part. After normalizing the cointegrating vector to estimate the error correction model (ECM) of the dynamic structure we have (Andrei and Bourbonnais, 2017):

$$
\mathrm{y}_{\mathrm{t}}=\alpha_{1}+\beta_{1} \mathrm{x}_{\mathrm{t}}+\varepsilon_{\mathrm{t}}
$$

where: 
Economic and Environmental Implications of Energy Taxes: Evidence from Romania

$\mathrm{y}_{\mathrm{t}}-$ is the dependent variable,

$\mathrm{x}_{\mathrm{t}}-$ is the independent variable,

$\alpha_{1}$ is the intercept,

$\beta_{1}$ is the coefficient of the independent variable, while

$\varepsilon_{t}$ is the random variable.

The error correction term can be obtained from the previous equation:

$\mathrm{EC}_{\mathrm{t}}=\mathrm{y}_{\mathrm{t}}-\alpha_{1}-\beta_{1} \mathrm{x}_{\mathrm{t}}$

Thus, the equation becomes:

$\Delta \mathrm{y}_{\mathrm{t}}=\mathrm{a}_{0}+\delta \mathrm{EC}_{\mathrm{t}-1}+\sum \mathrm{a}_{1 \mathrm{j}} \Delta \mathrm{y}_{\mathrm{t}-\mathrm{j}}+\sum \mathrm{a}_{2 \mathrm{j}} \Delta \mathrm{x}_{\mathrm{t}-\mathrm{j}}+\mathrm{u}_{\mathrm{t}}$

The model is valid only if the adjustment coefficient $\delta$ is negative. The size of the $\delta$ coefficient is an indication of the speed of adjustment towards equilibrium in that (Greene, 2011):

- small values of $\delta$, tending to -1 , indicate that economic agents remove a large percentage of disequilibrium in each period;

- larger values, tend to 0 , indicate that adjustment is slow;

- extremely small values, less than -2 , indicate an overshooting of economic equilibrium;

- a positive values would imply that the system diverges from the long-run equilibrium path.

Table 4. VECM and Granger causality tests

\begin{tabular}{lccc}
\hline \multicolumn{1}{c}{ Causality direction } & $\begin{array}{c}\text { Error correction } \\
\text { term (ECT) } \\
(p \text {-value })\end{array}$ & $\begin{array}{c}\text { Short-run } \\
\text { Coefficient } \\
(p \text {-value })\end{array}$ & $\begin{array}{c}\text { Lag coefficient } \\
(p \text {-value })\end{array}$ \\
\hline Energy taxes $\rightarrow$ GDP & $0.006895(0.87)$ & $0.126728(0.45)$ & $0.156304(0.59)$ \\
GDP $\rightarrow$ Energy taxes & -0.794294 & -0.276174 & $0.301813(0.14)$ \\
Energy taxes $\rightarrow$ CO2 & $(0.00)$ & $(0.42)$ & \\
& -0.263342 & -0.052501 & $0.422234(0.15)$ \\
CO2 $\rightarrow$ Energy taxes & $(0.02)$ & $(0.62)$ & -0.019209 \\
Energy taxes $\rightarrow$ Renewable & -0.418165 & -1.486351 & $(0.93)$ \\
energy & $(0.00)$ & $(0.02)$ & -0.171488 \\
Renewable energy $\rightarrow$ Energy & -0.469043 & $0.269248(0.04)$ & $(0.34)$ \\
taxes & $(0.00)$ & & 0.526137 \\
\hline
\end{tabular}

DOI: $10.24818 / 18423264 / 53.3 .19 .02$ 
Liviu Begu, Ioana Teodora Mester, Ramona Simut, Mariana Sehleanu, Diana Perticas

\begin{tabular}{lccc}
\hline Energy taxes $\rightarrow$ Non- & -0.416661 & $0.423488(0.66)$ & -0.073835 \\
renewable energy & $(0.04)$ & $(0.65)$ \\
Non-renewable energy $\rightarrow$ & -0.065182 & -0.182779 & -0.000449 \\
Energy taxes & $(0.87)$ & $(0.00)$ & $(0.99)$ \\
\hline
\end{tabular}

Source: authors' estimates using Eviews 9

The results show that the causal effect of the GDP, $\mathrm{CO}_{2}$ and Renewable energy variables on the Energy tax variable is significant in the long run, the estimated adjusted coefficients are statistically significant and relevant (as p-values < 0.05). The negative sign of these coefficients indicate that a long-run equilibrium characterized the relationship among the mention variables. According to the results we can affirm also that the GDP corrects the previous period disequilibrium faster than the other variables (79\% of this disequilibrium is corrected between $1^{\text {st }}$ year from GDP to Energy taxes). On the other hand, with regard to the long-term causal effect of the Energy taxes variable on the $\mathrm{CO}_{2}$, Renewable and Non-renewable energy variables, we observe that the negative values of the coefficients are lower than those mentioned above, indicating a reduced influence of energy taxes on these variables, or even nonsignificant in the GDP case $(\mathrm{p}$-value $=0.87)$. The short-run coefficients indicate convergence and significant results from $\mathrm{CO}_{2}$ and non-renewable energy to Energy taxes. Also the results offer evidence of overshooting short-term equilibrium from Energy taxes to Renewable energy. Regarding the short-term causal results of Energy taxes variable on GDP and non-renewable energy variables, the short-term causal results indicate divergence and non-significant coefficients.

To determine if the models above are valid, we also need to check the quality of the residue, namely: the normal distribution, the autocorrelation, and the homosceasticity. Thus, in the table below, we presented the probabilities of the tests associated with the three hypotheses on errors listed above.

Table 5. The probabilities of residual tests

\begin{tabular}{lccc}
\hline & $\begin{array}{c}\text { Breusch } \\
\text { Godfrey LM }\end{array}$ & ARCH LM & $\begin{array}{c}\text { Jarque- } \\
\text { Bera }\end{array}$ \\
\cline { 2 - 4 } Models based on causality direction & $\begin{array}{c}\mathrm{H}_{0}-\text { the errors } \\
\text { are } \\
\text { independent }\end{array}$ & $\begin{array}{c}\mathrm{H}_{0}-\text { the errors } \\
\text { are } \\
\text { homoscedastic }\end{array}$ & $\begin{array}{c}\mathrm{H}_{0}-\text { the } \\
\text { errors are } \\
\text { normally } \\
\text { distribute } \\
\mathrm{d}\end{array}$ \\
\hline Energy taxes $\rightarrow$ GDP & 0.1870 & 0.3057 & 0.3214 \\
GDP $\rightarrow$ Energy taxes & 0.3833 & 0.7402 & 0.0225 \\
Energy taxes $\rightarrow$ CO2 & 0.8669 & 0.2181 & 0.3376
\end{tabular}


Economic and Environmental Implications of Energy Taxes: Evidence from Romania

\begin{tabular}{llll}
\hline $\mathrm{CO} 2 \rightarrow$ Energy taxes & 0.3344 & 0.2701 & 0.8043 \\
$\begin{array}{l}\text { Energy taxes } \rightarrow \text { Renewable energy } \\
\text { Renewable energy } \rightarrow \text { Energy taxes }\end{array}$ & 0.6363 & 0.1449 & 0.9181 \\
$\begin{array}{l}\text { Energy taxes } \rightarrow \text { Non-renewable } \\
\text { energy }\end{array}$ & 0.5614 & 0.4957 & 0.1240 \\
$\begin{array}{l}\text { Non-renewable energy } \rightarrow \text { Energy } \\
\text { taxes }\end{array}$ & 0.5191 & 0.1003 & 0.8045 \\
\hline
\end{tabular}

Source: authors' estimates using Eviews 9

Given that the values of these probabilities are higher than the 5\% threshold (p-value $=0.05)$ and $1 \%$ threshold $(\mathrm{p}$-value $=0.01)$, then the null hypothesis is accepted as valid, which validates the correct representation of the residue of the estimated models. According to the results presented in Table 5, we can affirm that the null hypothesis is accepted for all these three residual tests, therefore, the correct representation of the residue of the estimated models is validated.

The long-run Granger causality running from the independent variables to dependent variable and the one-way short-run Granger causality are presented in the Figure 1. We have retained a number of one lag.

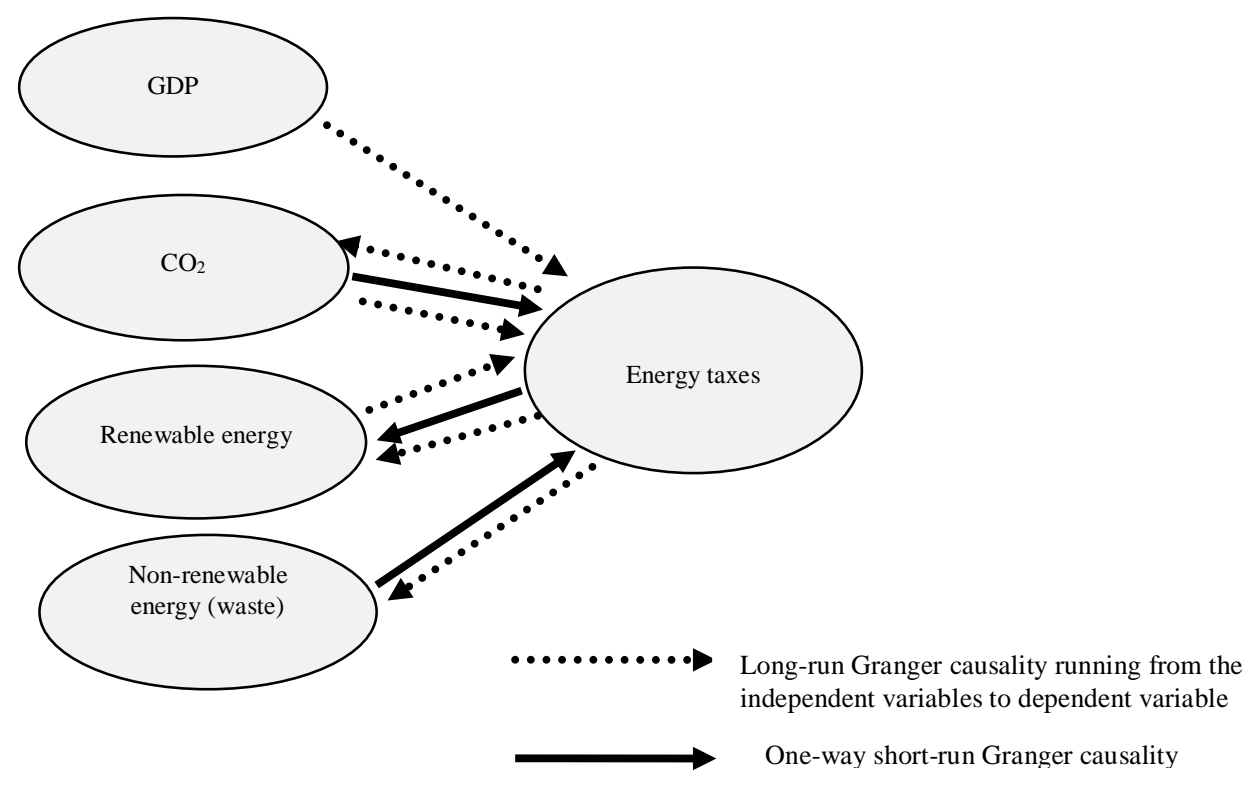

Figure 1. Granger causality relationship flows Source: Authors' contribution

DOI: $10.24818 / 18423264 / 53.3 .19 .02$ 
Liviu Begu, Ioana Teodora Mester, Ramona Simut, Mariana Sehleanu, Diana Perticas

The results of Granger causality relationship flows show that there is an evidence of long-run Granger causality running from: GDP to energy taxes, $\mathrm{CO}_{2}$ to energy taxes, renewable energy to energy taxes, respectively from energy taxes to $\mathrm{CO}_{2}$, renewable and non-renewable energy. Regarding the evidence of a short-run unidirectional causal relationship between variables, the results show that exist one from $\mathrm{CO}_{2}$ and non-renewable to energy taxes, respectively from energy taxes to renewable energy. There is no evidence of a short-run bidirectional causal relationship between the studied variables.

\section{Conclusions}

This paper aims to analyze the long-term and short-term relationship between energy taxes and several explanatory variables related to GDP, $\mathrm{CO}_{2}$, renewable energy and non-renewable taxes (waste). Certainly, these variables are influenced by a number of other factors such as productivity growth, human capital labor, and technological innovation.

It is worth mentioning here that the introduction of these taxes has the main purpose of reducing the level of pollution (both air and soil pollution). Even if the energy industry is one of the main $\mathrm{CO}_{2}$ generators, one should include here the metallurgical, chemical, paper and wood processing industries, and the extraction of fossil fuels etc., whose negative effects on the environment are not negligible at al. (Geir, 2008).

If we only look at the relationship between GDP and energy taxes, we can see that this link is a one-way relation i.e. GDP negatively affects energy taxes (see Table 4). A first explanation follows from results recorded in the more developed countries is that GDP growth determines the emergence of new technologies whose energy consumption is lower or even due to the development of technologies that use unconventional energy, in the case of those countries which enjoy an increase in energy efficiency.

As for the relationship between the energy taxes and renewable energy, the results provide some evidence of a long run bidirectional causal effect and a short run unidirectional causal effect from energy taxes to renewable energy. Therefore, an increase in energy taxes levels stimulates the production of conventional energy both in the short and the long run. This may be caused by the environmental policies that aim at reducing pollution levels in all areas, climate change issues, increasing energy security, reducing exposure to fossil fuels volatility prices. Although these energy taxes and renewable resources will most likely continue to grow, it is inappropriate to link them to economic development. As there has been seen in the research, the 
Economic and Environmental Implications of Energy Taxes: Evidence from Romania

increase in environmental taxes does not seem to have any significant impact on the economy.

From our analysis, we can notice that the use of non-renewable energy cause an increase in the energy taxes level at least in the short run. As we mentioned above, energy taxes were mainly introduced to reduce pollution levels, in theory being considered the easiest way to boost the production and use of clean technologies or at least of those that pollute less. Last but not least, it should not be forgotten that stimulating the production of renewable energy instead of conventional one is one of the national, European and even global goals.

\section{REFERENCES}

[1]Amri, F. (2017), The Relationship amongst Energy Consumption (Renewable and Nonrenewable), and GDP in Algeria. Renewable and Sustainable Energy Reviews, 76, 62-71. https://doi.org/10.1016/j.rser.2017.03.029;

[2]Andrei, T., Bourbonnais, R. (2017), Econometrie. Editia a doua revazuta si adaugata. Economica Publishing; Bucharest;

[3]Badulescu, D., Badulescu, A., Rangone, A., Sipos-Gug, S. (2016), Different or alike? Investigating the Impact of GDP on Environmental Protection Expenditure in Selected European States. Global \& Local Economic Review, 20(1), 55-75.

WOS:000393511600003;

[4]Bjørner, T.B., Jensen, H.H. (2002), Energy Taxes, Voluntary Agreements and Investment Subsidies-A Micro-Panel Analysis of the Effect on Danish Industrial Companies' Energy Demand. Resource and Energy Economics, 24(3), 229-249. https://doi.org/10.1016/S0928-7655(01)00049-5;

[5]Chen, P.-Y., Chen, S.-T., Hsu, C.-S., Chen, C.C. (2016), Modeling the Global Relationships among Economic Growth, Energy Consumption and $\mathrm{CO}_{2}$ Emissions. Renewable and Sustainable Energy Reviews, 65, 420-431.

https://doi.org/10.1016/j.rser.2016.06.074;

[6]Cioca, L.I., Ivascu, L., Rada E.C., Torreta, V., Ionescu, G. (2015), Sustainable Development and Technological Impact on $\mathrm{CO}_{2}$ Reducing Conditions in Romania . Sustainability, 7, 1637-1650. doi:10.3390/su7021637;

[7]Ekins, P., Pollitt, H., Summerton, P., Chewpreecha, U. (2012), Increasing Carbon and Material Productivity through Environmental Tax Reform. Energy

Policy, 42, 365-376. https://doi.org/10.1016/j.enpol.2011.11.094;

[8]Engle, R., Granger, C. (1987), Co-integration and Error Correction:

Representation, Estimation and Testing. Econometrica, 55(2), 251-276. http://links.jstor.org/sici?sici=0012-9682\%28198703\%2955\%3A2\%3C251\%3A-

CAECRE\%3E2.0.CO\%3B2-T\&origin=repec;

DOI: $10.24818 / 18423264 / 53.3 .19 .02$ 
Liviu Begu, Ioana Teodora Mester, Ramona Simut, Mariana Sehleanu, Diana Perticas

[9]Eurostat (2017), Energy Tax (extracted 11.12.17)

http://ec.europa.eu/eurostat/tgm/table.do?tab=table\&init=1\&plugin=1\&pcode=t2020_r t320\&-language=en. GDP per capita (extracted 11.12.17),

http://ec.europa.eu/eurostat/tgm/table.do?tab=table\&init=1\&language=en\&pcode=tec00001\&plugin $=1 .$, Renewable and non-renewable energy (extracted 11.12.17)

http://ec.europa.eu/eurostat/tgm/table.do?tab=table\&ini=1\&plugin-

$=1 \&$ pcode $=$ tsdpc $320 \&$ language $=$ en;

[10]Filipović, S., Verbič, M., Radovanović, M. (2015), Determinants of Energy

Intensity in the European Union: A Panel Data Analysis. Energy, 92, 547-555.

https://doi.org/10.1016/j.energy.2015.07.011;

[11]Fotis, P., Karkalakos, S., Asteriou, D. (2017), The Relationship between Energy Demand and Real GDP Growth Rate: The Role of Price Asymmetries and Spatial

Externalities within 34 Countries across the Globe. Energy Economics, 66, 69-84.

https://doi.org/10.1016/j.eneco.2017.05.027;

[12]Geir H. B., Taran F. (2008), Energy Taxation in a Small, Open Economy:

Social Efficiency Gains versus Industrial Concerns. Energy Economics, 30(4), 2050-

2071. https://doi.org/10.1016/j.eneco.2007.09.008;

[13]Greene, W.H. (2011), Econométrie, 7th ed. Pearson Education France, Paris, France;

[14]Johansen, S., Juselius, K. (1990), Maximum Likelihood Estimation and

Inference on Cointegration -with Application to the Demand for Money. Oxford

Bulletin of Economics and Statistics, 52, 169-210. doi:10.1111/j.1468-

0084.1990.mp52002003.x;

[15]Lin, B., Li, X. (2011), The Effect of Carbon Tax on Per Capita $\mathrm{CO}_{2}$ Emissions.

Energy Policy, 39, 5137-5146. https://doi.org/10.1016/j.enpol.2011.05.050;

[16]Moutinho, V., Madaleno, M., Robaina, M. (2017), The Economic and

Environmental Efficiency Assessment in EU Cross-Country: Evidence from DEA

and Quantile Regression Approach. Ecological Indicators, 78, 85-97;

https://doi.org/10.1016/j.ecolind.2017.02.042;

[17]Rahman, M.S., Noman, A. H. Md., Shahari, F. (2017), Does Economic Growth in Malaysia Depend on Disaggregate Energy?. Renewable and Sustainable Energy

Reviews, 78, 640-647. https://doi.org/10.1016/j.rser.2017.05.010;

[18]Ryan, L., Ferreira, S., Convery, F. (2009), The Impact of Fiscal and other

Measures on New Passenger Car Sales and $\mathrm{CO}_{2}$ Emissions Intensity: Evidence

From Europe. Energy Economics, 31, 365-374.

https://doi.org/10.1016/j.eneco.2008.11.011;

[19]Sarwar, S., Chen, W., Waheed, R. (2017), Electricity Consumption, Oil Price

and Economic Growth: Global Perspective. Renewable and Sustainable Energy

Reviews, 76, 9-18. https://doi.org/10.1016/j.rser.2017.03.063 ;

DOI: 10.24818/18423264/53.3.19.02 
Economic and Environmental Implications of Energy Taxes: Evidence from Romania

[20]Sundqvist P. (2007), Do Energy Taxes Decrease Carbon Dioxide Emissions?.

Master Thesis. Uppsala University; Department of Economics, [Online], Available:

https://www.diva-portal.org/smash/get/diva2:131515/FULLTEXT01.pdf;

[21]Teodoroiu, S.M. (2003), Răspunderea civilă pentru dauna ecologică. Lumina-

Lex Publishing House, Bucharest;

[22]Turnock, D. (2005), The East European Economy in Context Communism and Transition. Toutledge, New York;

[23]Vandyck, T., Van Regemorter, D. (2014), Distributional and Regional

Economic Impact of Energy Taxes in Belgium. Energy Policy, 72, 190-203.

https://doi.org/10.1016/j.enpol.2014.04.004;

[24]Verbič, M., Filipović, S., Radovanović, M. (2017), Electricity Prices and

Energy Intensity in Europe. Utilities Policy, 47, 58-68.

https://doi.org/10.1016/j.jup.2017.07.001;

[25]The World Bank (2017), CO2 emissions, 1995-2013, (extracted 11.12.17)

http://databank.worldbank.org/data/reports.aspx?Code=NY.GDP.PCAP.CD\&id=1ff4a

$\underline{498 \& \text { report_name }=\text { Popular-Indicators } \& \text { populartype }=\text { series } \& \text { ispo-pular }=y}$.

DOI: 10.24818/18423264/53.3.19.02 